\title{
Water for Wildlife in India
}

\author{
By Anne Wright
}

$\mathbf{T}$ HE Palamau jungles in Bihar in north-east India consist of sal forests in undulating country. In January this year it was clear that the unprecedented drought was going to affect the wild animals very seriously, and while help was forthcoming for the people and their domestic animals there was none for the wildlife. The failure of the monsoon rains for two consecutive years with the resultant loss of crops brought grim tragedy for the villages, and to add to the distress the water level in the whole of Bihar has gone down.

With money kindly sent by the Animal Welfare Board, Madras, and other emergency donations, including $£ 50$ very kindly donated by the Fauna Preservation Society, my husband and I with some volunteers were able to start proceedings. The Chief Conservator of Forests, Bihar, Mr. S. P. Shahi, a very enlightened and keen conservationist, allocated to us three jungle blocks in which to operate, with a forest bungalow as a base. He visited us there, and I accompanied him on tours to other areas in an effort to awaken forest officialdom at all levels to the seriousness of the drought, and to see what waterholes had been provided for animals. The heat ranging to 116 degrees Fahrenheit was unbearable as we drove through hundreds of miles of parched dry jungle. Every river was dry, and nullahs which sometimes contain natural pools in normal years had dried up, some for the first time in living memory.

The situation in the 200-square-mile area was horrifying. In Kumandih Block the three small waterholes dug by the Forest Department in March held only two to three inches of water, and by mid-May had dried up. In the hills the local tribal people showed us two small stagnant rock pools which were closely overlooked and surrounded by freshly made poachers' hides. The only oasis was the small sanctuary of Betla, where the Forest Department had installed water-troughs which were filled daily by a jeep water tanker. The wild elephants had left the sanctuary in March in search of water, but herds of gaur, the Indian bison, cheetal, sambhar, wild boar and barking deer could be seen congregated at these waterholes in the mornings and evenings.

The first task was to establish a main source of water supply; since there were no UNICEF pumps within 50 miles, we found it by digging deeply into the dry bed of the Auranga river. Mr. N. K. Chaudhuri supervised the making of a 12-foot-square hole, and installed a handpump and pipes to enable drums brought by jeep trailer to be filled. In the nullahs that were dry we installed 45-gallon drums cut lengthwise to form tin troughs which we filled daily by jeep trailer; they were immediately used by small herds of cheetal, barking deer, peafowl, red junglefowl and myriads of small birds. Panther pugmarks, bison, wild pig, porcupine and monkey marks were also found, while near our hole in the Auranga there were pugmarks of three tigers in the sand. Tribal people, out in the forest picking biri 
leaves to sell and roots and berries to eat, drank in the daytime from these troughs, while cattle often drained them dry.

All shooting had been banned during the drought but this had no effect on the local poachers. We were astounded at the scale on which they operated. Shotguns and muzzle loaders licensed to protect crops are used continuously for killing both deer and gaur, now fully protected in Bihar, at water holes in the summer and at salt licks during the rains; the meat is sold. At every water hole we found hides made of branches, and in certain places hides of a more permanent nature had been carefully built of stones and boulders, with loopholes to fire out of. We destroyed 23 hides and one machan, but they were invariably rebuilt. A Government official, caught shooting a sambhar by spotlight from a jeep, was prosecuted, and army vehicles whose numbers were taken by foresters at night were reported to the Area Commander.

The RSPCA have now donated $£ 500$ specifically for wild life in Palamau, and two model dams are being built in the hope that the Forest Department may build more in other areas; they will be protected by forest guards against poachers. The lack of transport is a difficulty, but we hope for further donations to buy a jeep. These dams will bring permanent relief to the wildlife in the parched summer months and ensure that this year's calamity will not occur again. The State is lucky in having a keen conservationist, Mr. S. P. Shahi, as its Chief Conservator and under his guidance there are already signs that the game laws are more strictly adhered to.

Since this article was written the monsoon rains have brought floods to northern Bihar. The Palamau jungles in the south are once again lush and green, but there is no room for complacency. In the fiercely hot and dry summer months the Palamau National Park and the surrounding jungles are always acutely short of water, and now that the water level has fallen it is more than ever urgent to build permanent watering places.

Donations to help in this work can be sent to the "Save the Wild Life Fund", at the National and Grindlays Bank, 13 St. James' Square, London S.W.1. or 6 Church Lane, Calcutta.

\section{Manipur Deer and Indian Wild Ass}

I $T$ looks as though the hydroelectric scheme in India which it was feared might 1 threaten the safety of the rare Manipur brow-antlered deer will in fact benefit the deer indirectly. Mr. E. P. Gee reports that the scheme, by reducing the level of the Logtak Lake would reduce the level in the deer's sanctuary; but it would also keep the water level constant, eliminating the flooding which at times forces the deer to move outside the 10-square-mile sanctuary to higher ground where they may be in danger from poachers. With no flooding they are likely to stay inside. Another rare animal in India, confined to one small area and recently thought to be threatened, is the Indian wild ass, now numbering some 850 animals on the Little Rann of Kutch. The threat here is cultivation of their desert range, but the Chief Conservator of Forests of Gujarat State has assured Mr. Gee that there will be no cultivation for at least 15 years, and that even then the major part of the Little Rann will not be touched. 